\title{
New antibody approaches to lymphoma therapy
}

\author{
Tejas Suresh ${ }^{1}$, Lisa X Lee ${ }^{1}$, Jitesh Joshi ${ }^{1}$ and Stefan K Barta ${ }^{2 *}$
}

\begin{abstract}
The CD20-directed monoclonal antibody rituximab established a new era in lymphoma therapy. Since then other epitopes on the lymphoma surface have been identified as potential targets for monoclonal antibodies $(\mathrm{mAb})$. While most mAbs eliminate lymphoma cells mainly by antibody-dependent cellular cytotoxicity, complement-dependent cytotoxicity or direct cell death, others counter mechanisms utilized by malignant cells to evade immune surveillance. Expression of PD-L1 on malignant or stromal cells in the tumor environment for example leads to T-cell anergy. Targeting either PD-1 or PD-L1 via mAbs can indirectly eliminate cancer cells by unblocking the host intrinsic immune response. Yet another mechanism of targeted therapy with mAbs are bi-specific T-cell engagers (BiTE) such as blinatumomab, which directly engages the host immune cells. These examples highlight the broad spectrum of available therapies targeting the lymphoma surface with mAbs utilizing both passive and active immune pathways. Many of these agents have already demonstrated significant activity in clinical trials. In this review we will focus on novel CD20-directed antibodies as well as mAbs directed against newer targets like CD19, CD22, CD40, CD52 and CCR4. In addition we will review mAbs unblocking immune checkpoints and the BiTE blinatumomab. Given the success of mAbs and the expansion in active and passive immunotherapies, these agents will play an increasing role in the treatment of lymphomas.
\end{abstract}

Keywords: Bispecific T-cell engager, Cd-20, Pd-1, Cd-22, Monoclonal, Lymphoma, Antibodies

\section{Introduction}

In 1997 the CD20-directed monoclonal antibody (mAb) rituximab became the first $\mathrm{mAb}$ approved for the treatment of lymphoma after it demonstrated significant single agent activity in indolent B-cell lymphomas [1]. Since then rituximab has become an indispensable component in the treatment of all types of B-cell NonHodgkin lymphomas (NHL), both alone and in combination with chemotherapeutic agents [2].

While rituximab can lead to direct cytotoxicity by induction of apoptosis, it also eliminates lymphoma cells by antibody-dependent cellular cytotoxicity (ADCC) and complement-dependent cytotoxicity [3]. Its success has spawned an immense interest in using the hosts' immune system in selectively targeting tumor cells by attacking tumor-specific surface antigens. These surface epitopes represent ideal targets as they allow effective anticancer therapy while relatively sparing normal tissues.

mAbs represent the cornerstone of passive immunotherapy, which involves engineering of $\mathrm{B}$ or $\mathrm{T}$ cell receptors

\footnotetext{
* Correspondence: Stefan.barta@fccc.edu

${ }^{2}$ Fox Chase Cancer Center, Philadelphia, PA, USA

Full list of author information is available at the end of the article
}

targeting a desired antigen and infusion into patients with disease. Methods to potentially increase their efficacy include conjugation of mAbs with potent cell toxin or radioisotopes, exemplified by antibody-drug conjugates (ADC) and radioimmunotherapy (RIT) respectively. Another more recent mode of passive immunotherapy is termed adoptive T-cell transfer: autologous T-cells with genetically modified T-cell receptors (chimeric antigen receptors; CARs) that specifically recognize a tumor epitope are reinfused and exert their newly acquired antilymphoma potency in the host [4]. BiTEs or bispecific T cell engagers are also examples for newer passive therapy that activates $\mathrm{T}$ cell destruction of lymphoma cells.

Active immunotherapy on the other hand enables the patient's own immune system to re-engage into recognizing malignant cells which originally escaped immune surveillance. The classical example for active immunotherapy is tumor vaccines. More recently antibodies directed against CTLA4 or the PD-1/PD-L1 pathway, which unblock immune checkpoints, have demonstrated significant antitumor activity [3].

This review focuses on recent advances in targeting the lymphoma surface directly or indirectly with mAbs 
representative of active and passive immunotherapies (Figure 1), and agents that have either just reached the clinical practice or hold promise to change standard of care. Lymphoma therapy with ADCs, RIT, vaccines or adoptive T-cell transfer is reviewed elsewhere [3,5-7].

\section{Monoclonal antibodies against B-cell antigens Targeting CD20}

CD20 is a surface antigen found on all mature B-cells. Its main function is to activate B-cells, allowing proliferation and differentiation. As it is also present on most mature B-cell NHL cells, it represents an ideal therapeutic target. While mAbs against CD20 target mature B-cells, they spare B cell progenitors, allowing normal B-cell regeneration [2].

Rituximab was the first $\mathrm{mAb}$ to target $\mathrm{CD} 20$ and represents a type I mAbs that cause cell death through: [8] a direct apoptotic effect; complement-dependent cytotoxicity (CDC), in which binding of the mAb activates the complement cascade; and ADCC, in which immune cells expressing Fcy receptors attack antibody-coated cells. Certain polymorphisms in the FcyRIIIa protein alter activation of effector cells causing less ADCC and result in significantly lower response rates (RR) following rituximab monotherapy [9-11]. Newer mAbs are being designed to better target carriers of these polymorphisms (Table 1).

Obinutuzumab (GA101; Gazyva ${ }^{\mathrm{mm}}$ ) represents a type II $\mathrm{mAb}$; while type I mAbs work primarily through CDC by stabilizing CD20 on lipid rafts, type II mAbs work mainly by direct cell death and ADCC [12-15]. Obinutuzumab is a glycoengineered CD20 mAb derived from the murine Bly-1 antibody [16]. Afucosylation (which increases affinity to Fc gamma receptor IIIa) of the Fc

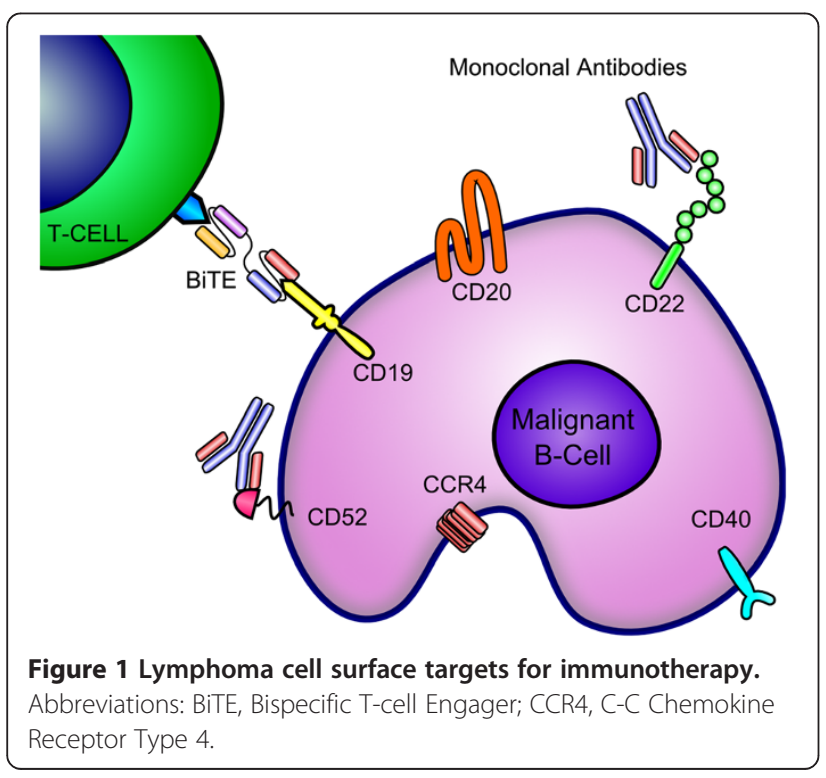

region leads to improved activation of effector cells [17]. leading to BCL-2 and caspase independent apoptosis, and hypothetically circumvents resistance [12]. As compared to rituximab, it results in increased $\mathrm{ADCC}$ and direct apoptosis both in vitro and in vivo $[9,17]$. Type II mAbs are thought to have an advantage because type I mAbs are faced with complement-resistance factors, depletion of complement proteins [18], and bind C1q, which interferes with FcyR binding and decreases ADCC [19]. Furthermore, type II mAbs result in longer persisting anti-CD20 mAb complexes [20] and higher binding affinity thereby increasing ADCC.

In November 2013, obinutuzumab was FDA approved for the treatment of previously untreated CLL in combination with chlorambucil $(\mathrm{Cb})$. In a phase 3 study in treatment naïve elderly patients, $\mathrm{Cb}$ with obinutuzumab showed superior RR and progression free survival [PFS] compared to $\mathrm{Cb}$ alone and $\mathrm{Cb}$ with rituximab (complete response $[\mathrm{CR}$ ] rate 21\%; overall response rate [ORR] $78 \%$ ) [21]. In addition, obinutuzumab has been tested in combination with other chemotherapeutic agents in CLL [22] and more aggressive B-cell NHL, such as diffuse large B-cell lymphoma (DLBCL) and mantle cell lymphoma (MCL) [23], demonstrating promising results. The main non-hematologic side effects (SE) were grade 1 or 2 infusion-related reactions (IRRs) and the most common hematologic SE was neutropenia.

\section{Ofatumumab}

Ofatumumab (HuMax-CD20; Arzerra ${ }^{\circ}$ ) is another humanized CD20-directed mAb. It binds to both loop domains of CD20 at a different epitope than rituximab and induces CDC [24]. As compared with rituximab and obinutuzumab, ofatumumab results in the greatest complement activation and antibody-dependent phagocytosis (ADP) [25].

Ofatumumab is FDA-approved in combination with chlorambucil for the treatment of CLL patients for whom fludarabine-based therapy is considered inappropriate [26] and those who are refractory to fludarabine and alemtuzumab [27]. The most common SE were IRRs and infections that were grade I/II events. Additionally, in combination with pentostatin and cyclophosphamide it compared favorably to historical controls treated with fludarabine, cyclophosphamide and rituximab (FCR) [28-30]. When combined with fludarabine and cyclophosphamide (O-FC) the results were comparable to what has been reported with other similar chemoimmunotherapy (CIT) regimens [31]. Trials directly comparing rituximabbased CIT to ofatumumab-based CIT in CLL are currently ongoing.

Ofatumumab has also been tested in indolent and aggressive NHL either as single agent or in combination with chemotherapy [32-35]. It appears that while the 
Table 1 Anti-CD20 monoclonal antibodies currently approved or being investigated in clinical trials for B-cell lymphomas

\begin{tabular}{|c|c|c|c|c|c|c|c|c|}
\hline $\mathrm{mAb}$ & $\begin{array}{l}\text { Type of CD20 } \\
\text { antibody* }\end{array}$ & Generation $^{* *}$ & Structure & $\begin{array}{l}\text { Mechanism of action } \\
\text { (ADCC/CDC/PCD) }\end{array}$ & Comparison to rituximab & $\begin{array}{l}\text { Indications } \\
\text { tested }\end{array}$ & Phase of development & References \\
\hline Rituximab & । & 1 & $\begin{array}{l}\text { IgG1 Human Mouse } \\
\text { chimeric }\end{array}$ & $++/++/+$ & - & $\mathrm{NHL/CL/DLBCL}$ & $\begin{array}{l}\text { FDA approved for NHL, CLL, } \\
\text { DLBCL }\end{array}$ & {$[8-11]$} \\
\hline $\begin{array}{l}\text { Obinutuzumab (GA101; } \\
\text { Gazyva'TM) }\end{array}$ & $\|$ & 3 & $\begin{array}{l}\text { Murine bly-I derived } \\
\text { humanized IgG1 }\end{array}$ & $++++/-/++++$ & Superior PCD/ADCC; no CDC & CLL/NHL & $\begin{array}{l}\text { Phase } 2 / 3 \text { Approved in } 2013 \\
\text { for untreated CLL in } \\
\text { combination with Clb }\end{array}$ & {$[12-20]$} \\
\hline $\begin{array}{l}\text { Ofatumumab (HuMax- } \\
\left.\text { CD2O; Arzerra }^{\oplus}\right)\end{array}$ & I & 1 & Fully human $\lg G 1$ & $+++/++++/++$ & Superior CDC, decreased PCD & $\mathrm{CLL} / \mathrm{NHL}$ & $\begin{array}{l}\text { Phase } 2 / 3 \text { Approved for } \\
\text { untreated CLL in } \\
\text { combination with } \mathrm{Clb} \& \\
\text { refractory CLL }\end{array}$ & {$[21-35]$} \\
\hline Veltuzumab & I & 2 & Humanized lgG1 & $++/++/+$ & $\begin{array}{l}\text { Longer "off-rate", more avid } \\
\text { CD20 binding. can be given } \\
\text { subcutaneously }\end{array}$ & R/R NHL/CLL & Phase $1 / 2$ & {$[36-38]$} \\
\hline Ocrelizumab & । & 2 & Humanized fusion lgG1 & $+++/+/+$ & Enhanced binding to FCyRlla & $\mathrm{NHL}$ & Phase 3 & {$[39]$} \\
\hline LY2469298 & I & 3 & $\begin{array}{l}\text { Modified Fc region } \\
\text { human } \operatorname{lgG1}\end{array}$ & $+++/++/++$ & $\begin{array}{l}\text { Enhanced Fc binding; superior } \\
\text { ADCC }\end{array}$ & $\mathrm{NHL}$ & Phase $1 / 2$ & {$[40]$} \\
\hline BM-ca & $\mid / \|^{* * *}$ & 3 & Humanized lgG & $++++/+++/++++$ & $\begin{array}{l}\text { Different epitope, superior } \\
\text { ACDD, CDC and PCD }\end{array}$ & $\mathrm{NHL}$ & Phase 1 & {$[42-44]$} \\
\hline
\end{tabular}

ADCC: Antibody dependent cellular cytotoxicity; CDC: Complement dependent cytotoxicity; Clb: chlorambucil; CLL: Chronic lymphocytic leukemia; DLBCL: Diffuse large B cell lymphoma; PCD: programmed cell death; mAb: Monoclonal antibody; Moa: Mechanism of action; NHL: Non-Hodgkin lymphoma.

*Type of mAb: compared to a type I mAb, a type 2 mAb does not evoke a complement response, however, may have increased PCD/ADCC.

${ }^{* *}$ Generations of $\mathrm{mAB}$.

$1^{\text {st }}$ generation: originally approved $\mathrm{mAB}$ against a clinically validated target $2^{\text {nd }}$ generation: follow-up antibodies with improved variable domains that target the same epitopes with higher or lower affinity, or have different antibody formats, e.g. Pegylation and Fc-fusion proteins. $3^{\text {rd }}$ generation: target different epitopes or trigger other mechanisms of action; often engineered for improved Fc-associated immune functions or half-life.

***BM-ca demonstrates properties of both Types I and II mAbs. 
toxicities are similar to rituximab-based therapy the efficacy compares favorably.

\section{Veltuzumab}

Veltuzumab is a humanized anti-CD20 mAb that was constructed on the framework regions of the anti-CD22 $\mathrm{mAb}$ epratuzumab (see below). Structurally it differs from rituximab by only one amino acid. It has a significantly higher potency than rituximab in preclinical models, exhibiting a greater CDC and possessing a slower off-rate resulting in longer cell surface retention [36].

In a phase $1 / 2$ study of 82 patients with refractory $\mathrm{NHL}$, the drug was well tolerated, with no serious side effects. In patients with follicular lymphoma (FL) who had prior exposure to rituximab, veltuzumab was associated with an ORR of $44 \%$ and a CR rate of $27 \%$ [37]. RR were higher in rituximab-naïve patients (ORR 57\%; CR/ $\mathrm{CRu}$ (unconfirmed CR) rate 43\%). Among non-follicular histologies, the ORR was $35 \%$, with $27 \%$ achieving a CR. Although developed for IV use, veltuzumab has been shown to have similar efficacy as a SQ injection [38].

\section{Ocrelizumab}

Ocrelizumab is another humanized IgG1 anti-CD20 $\mathrm{mAb}$. It differs from rituximab at the complementaritydetermining regions, and is derived from a different allotype of human Fc. Like rituximab, ocrelizumab works through ADCC, CDC and apoptosis, although it has been shown to have better ADCC and lower CDC. Importantly, ocrelizumab has better binding to the lowaffinity variants of the Fcy receptor IIIa. Patients with the high affinity variant of FcyRIIIa have shown superior outcomes following rituximab compared with patients with the low affinity variant; thus it is hypothesized that ocrelizumab may have better clinical efficacy $[9,11]$. In a phase $1 / 2$ trial, ocrelizumab was tested as single agent in patients with relapsed/refractory (R/R) FL [39]. Overall, the drug was well tolerated, (a similar safety profile as rituximab monotherapy) with an ORR of $38 \%$, which is comparable to rituximab re-treatment.

\section{LY2469298}

LY2469298 (AME-133v) is a humanized IgG1 anti-CD20 $\mathrm{mAb}$ with a 13-20 fold higher affinity to CD20 than rituximab. A limited number of amino acid substitutions in the $\mathrm{Fc}_{\mathrm{c}}$ region of the $\mathrm{mAb}$ result in enhanced ADCC (6-fold more potent in vitro) but with $50 \%$ less CDC compared with rituximab [40]. and potentially more efficacy than rituximab in those patients who were carriers of the low affinity FcyRIIIa allele. In a phase 1 trial of patients with previously treated FL who were FCyRIIIa carriers, the drug was well tolerated; responses (PR or CR) were observed in $22 \%$ of patients [41]. In a Japanese phase 1 study the ORR was $50 \%$ in previously rituximab-treated FL patients carrying the FCyRIIIa variant [40].

\section{BM-ca}

$\mathrm{BM}$-ca is a novel mAb targeting CD20 that recognizes a unique epitope as compared to rituximab, and was stronger than rituximab in ADCC and direct anti-cell proliferation assays $[42,43]$. In phase I studies, it was shown to be well tolerated with promising preliminary anti-lymphoma activity in B cell NHL (2 CR and 2 PR out of 12 patients) [44].

\section{Targeting CD22}

CD22 is a sialic acid-binding immunoglobulin (Ig)-like lectin involved in cellular adhesion, regulation of B-cell homing and modulation of B-cell activation [45]. It is expressed by pre-B, mature, and normal B-cells as well as in many malignant B-lymphocytes [46]. During early B-cell development it is found in the cytoplasm, then on the cell surface of mature B-cells [47]. Quickly internalized when bound by mAbs, it is then re-expressed on the cell membrane after modulation, a property not found in CD20 [48,49]. This, and the role CD22 plays in B-cell signaling, makes it an ideal target in lymphoid B-cell malignancies (Table 2).

\section{Epratuzumab}

The mAb targeting CD22 furthest along in development is the IgG1 humanized mAb, epratuzumab. The actual mechanism of epratuzumab has not been formally explored, but it is reasonable to assume that it includes ADCC, CDC and direct cytotoxicity [50]. Single agent epratuzumab has been studied in indolent as well as aggressive NHL. In an early phase $1 / 2$ trial, epratuzumab was well tolerated and showed the best response in FL (ORR 24\%) [51], while 15\% of patients with DLBCL showed a response [52]. The drug was very well tolerated, with no dose-limiting toxicity.

Epratuzumab plus rituximab has been tested in $R / R$ NHL and compared to single agent use, resulted in a higher ORR of $47 \%$ with the highest RR again in FL (64\%) [53]. Another multicenter trial showed an ORR of $54 \%$ for patients with FL and 57\% for small lymphocytic lymphoma (SLL) [54]. The combination of epratuzumab with rituximab was also studied in patients with newly diagnosed FL, and the RR of was $88.2 \%$ [55].

In aggressive lymphomas, when combined with $\mathrm{R}$ CHOP for patients with DLBCL, the ORR was 96\% [50], which compares favorably with studies using R-CHOP for upfront treatment. Of note, approximately $15 \%$ of patients with DLBCL do not express CD22; in this trial CD22-negative patients were ineligible [56].

\section{Targeting CD19}

CD 19 is a transmembrane glycoprotein that is expressed by normal and malignant B-cells from early 
Table 2 Monoclonal antibodies directed against non-CD20 surface epitopes

\begin{tabular}{|c|c|c|c|c|c|c|}
\hline $\mathrm{mAB}$ & Target & Structure & Unique properties & Indication tested & $\begin{array}{l}\text { Phase of } \\
\text { development }\end{array}$ & References \\
\hline Epratuzumab & CD22 & Humanized lgG1 & Enhanced ADCC, no PCD & $\mathrm{NHL} / \mathrm{DLBCL}$ & Phase $1 / 2$ & {$[50-56]$} \\
\hline Medi 551 & CDI9 & $\begin{array}{l}\text { Afucosylated humanized } \\
\text { lgG1 }\end{array}$ & Enhanced ADCC, no CDC & $\mathrm{NHL/DLBCL/ALL}$ & Phase $1 / 2$ & {$[60,61]$} \\
\hline Lucatumumab & CD4O & Humanized lgG1 & $\begin{array}{l}\text { Also being tested in } \\
\text { myeloma. ADCC }\end{array}$ & $\begin{array}{l}\text { NHL/CLL/HL/MZL/ } \\
\text { MALT }\end{array}$ & Phase $1 / 2$ & {$[64,69,70]$} \\
\hline Dacetuzumab & $\mathrm{CD} 4 \mathrm{O}$ & Humanized lgG1 & $\begin{array}{l}\text { Partial agonist. Enhanced } \\
\text { ADCC/CDC/PCD }\end{array}$ & DLBCL & Phase 1 & {$[71-76]$} \\
\hline $\begin{array}{l}\text { Alemtuzumab } \\
\left.\text { (Campath }^{\circledast}\right)\end{array}$ & CD 52 & Humanized lgG1 & Enhanced ADCC/CDC/PCD & $\begin{array}{l}\mathrm{CLL} / \mathrm{T} \text {-Cell NHL } \\
\text { Approved for } \\
\text { del17p CLL }\end{array}$ & Phase $2 / 3$ & {$[81-89]$} \\
\hline Mogalizumab & CCR4 & $\begin{array}{l}\text { Afucosylated humanized } \\
\text { lgG1 }\end{array}$ & Enhanced ADCC & PTCL/CTCL & Phase $1 / 2$ & [91-98] \\
\hline Pidilizumab (CT-011) & PD-1* & $\begin{array}{l}\text { Humanized lgG1 Kappa } \\
\text { recombinant }\end{array}$ & Reverses T-cell anergy & $\mathrm{NHL/DLBCL}$ & Phase $1 / 2$ & [101-113] \\
\hline Blinatumomab & BiTE (CD3/CD19) & $\begin{array}{l}\text { Single-chain bispecific } \\
\text { antibody construct with } \\
\text { variable regions of two } \\
\text { antibodies. }\end{array}$ & Bispecific T-cell Engager & DLBCL/ALL & Phase 2/3 & [118-120] \\
\hline
\end{tabular}

ADCC: Antibody dependent cellular cytotoxicity; ALL: Acute lymphoblastic leukemia; BiTE: Bispecific T-cell Engager; CDC: Complement dependent cytotoxicity; CLL: Chronic lymphocytic leukemia; CTCL: Cutaneous T Cell Lymphoma; DLBCL: Diffuse large B cell lymphoma; HL: Hodgkin lymphoma; mAB: Monoclonal antibody; MALT: Mucosa associated Lymphoid tissue lymphoma; Moa: Mechanism of action; MZL: Marginal zone lymphoma; NHL: Non Hodgkin lymphoma; PCD: programmed cell death; PTCL: Peripheral T Cell Lymphoma.

*PD1 is mainly expressed on regulatory T cell surface, while its ligand PDL-1 is often expressed on malignant cells. Stimulation of this pathway results in immune anergy towards malignant cells.

pre-B maturation to terminal plasma cell differentiation $[57,58]$. It is found on a wide range of B-cell malignancies, including those arising from early B-cell precursors, which cannot be effectively targeted with CD20 Abs [57]. Like CD22, but unlike CD20, it is also efficiently internalized. Its function encompasses regulating cell signaling thresholds and serving as a co-stimulatory molecule for B-cell receptor (BCR) signaling [59].

\section{MEDI-551}

MEDI-551 is an afucosylated anti-human CD19 mAb with in vitro and in vivo activity against lymphoma [60]. Results from a phase 1 trial of single agent MEDI-551 in R/R B-cell malignancies show an acceptable safety profile and ORR of $24 \%, 24 \%$, and $31 \%$ in heavily pre-treated CLL, DLBCL and FL patients respectively [61]. Phase 2 trials in DLBCL patients are currently recruiting.

\section{Targeting CD40}

CD40 is a type- 1 transmembrane protein and expressed in more than $90 \%$ of B-cell malignancies [62-65]. It is thought to have a greater range of expression than CD20 and is present in the pro-B to the plasma cell phase of B-cell development. Studies have showed that activation of CD40 results in enhanced survival of neoplastic B-cells, thus targeting CD40 with mAbs could help block this [64]. Additionally, CD40 signaling impacts resistance mechanisms to chemotherapy. In CLL, CD40 activation triggers phosphorylation of ERK1/2 and IKK, and up-regulates $\mathrm{Mcl}-1$ and $\mathrm{Bcl}-\mathrm{xl}$, which creates a malignant phenotype [64]. Similar mechanisms have been shown in Hodgkin lymphoma (HL) [66]. The prognostic significance of CD40 expression on lymphoma cells [67] and/or the bone marrow stromal cells [68] as well as the impact of CD40related BCR signaling are areas of ongoing investigation.

\section{Lucatumumab}

Lucatumumab, a human anti-CD40 mAb, was shown to cause more B-cell lysis than rituximab in preclinical models [64]. In a phase 1 trial in CLL, stable disease (SD) was observed in 17 of 26 patients [69]. In another phase 1/2 trial of 111 patients with R/R NHL or HL, the drug was well tolerated with ORR of $33 \%$ in FL patients and $11 \%$ in those with DLBCL and marginal zone lymphoma (MZ) [70].

\section{Dacetuzumab}

Dacetuzumab is another CD40 mAb that acts as a partial agonist at the CD40 receptor [71]. It works through direct signal transduction, ADCC and ADP [71]. In lymphoma xenograft models it demonstrates synergy with rituximab and gemcitabine [72]. Dacetuzumab monotherapy appears to be well tolerated and without major adverse events (AEs) $[73,74]$. When combined with rituximab and gemcitabine for elderly patients with R/R DLBCL ( $n=33) 47 \%$ achieved a response (20\% CR) [75]. These results are 
comparable to the efficacy of R-GemOx in the $2^{\text {nd }}$ - line setting for DLBCL [76].

\section{Targeting CD 52}

The CD52 antigen is a cell surface glycoprotein of unknown function that is expressed on both $\mathrm{B}$ - and T-lymphocytes [77]. It is recognized by a humanized $\mathrm{mAb}$ named alemtuzumab, which works by complementinduced cell lysis, direct cell-mediated cytotoxicity and induction of apoptosis [78-80].

\section{Alemtuzumab}

Alemtuzumab (Campath ${ }^{\circ}$ ) first received accelerated approval in the U.S. in 2001 for CLL patients who had failed fludarabine. Then, based on the results of a trial comparing alemtuzumab to chlorambucil as 1st-line treatment, it received full approval in 2007 in the U.S. and 2008 in Europe $[81,82]$. The subgroups that appeared to benefit the most included patients with $17 p$ deletion, bone marrow infiltration and refractory autoimmune cytopenia [83]. In T-cell lymphomas (TCL), alemtuzumab has shown efficacy as a single agent and in combination with conventional chemotherapy in $R / R$ or untreated peripheral TCL (PTCL) as well as in advanced cutaneous TCL (CTCL) [84-86].

More recent trials looked at improving the safety profile of alemtuzumab, and its effectiveness in combination with other regimens. Previous trials with alemtuzumab had been associated with significant toxicity, stemming mainly from profound immunosuppression. Lower doses of alemtuzumab showed similar effectiveness with a better safety profile [87]. Subcutaneous alemtuzumab in combination with rituximab in fludarabinerefractory CLL patients was also well-tolerated and allowed patients to achieve adequate cytoreduction prior to stem cell transplantation [88]. A recent phase 2 trial tested alemtuzumab consolidation after $\mathrm{CHO}(\mathrm{E})$ P-14 in 41 patients with untreated PTCL [89]. While the combination was quite effective $(59 \%$ of patients achieved a CR), it was associated with significant treatment-related adverse events (the main grade $3 / 4$ toxicities were infections and neutropenia, including one potentially treatment-related death). Therefore, although alemtuzumab is an active drug in lymphomas, its use has been limited by its toxicities.

\section{Targeting CCR4}

The chemokine receptor CCR4 is expressed on a subset of Type 2 helper $\left(\mathrm{T}_{\mathrm{H}}\right)$ and regulatory T-cells (Treg) and is involved in lymphocyte trafficking. Many adult PTCL express both CCR4 and its ligands. CCR4 (+) T-cell lymphomas are associated with a poorer prognosis, possibly because of downregulation of T-cell mediated antitumor host response [90]. Mogamulizumab
(KW-0761) is a mAb that targets CCR4(+) tumor cells by ADCC and downregulates Treg trafficking to the tumor microenvironment.

\section{Mogamulizumab}

Preliminary data shows responses in a subset of T-cell lymphomas with traditionally poor prognosis. In a phase 1 trial of 16 patients with R/R CCR4(+) mature T-cell lymphomas, $31 \%(\mathrm{n}=5)$ achieved a response (CR: 13\%; $\mathrm{n}=2$ ) [91]. Results of a phase 2 trial in 28 patients with R/R CCR4(+) adult T-cell leukemia/lymphoma (ATLL) showed an ORR of $50 \%$, a median PFS of 5.2 months and OS of 13.7 months, which lead to its approval in Japan for this indication [92]. A US trial of single agent mogamulizumab in patients with both $\operatorname{CCR} 4(+)$ and CCR4(-) R/R CTCL $(n=38)$ demonstrated an ORR of $35 \%$ [93]. In a consecutive study in patients with CCR4(+) PTCL or CTCL $(n=38)$, the ORR was $35 \%(n=13)$ and $14 \%(\mathrm{n}=5)$ showed a CR with a median PFS of 3 months [94]. Infusion reactions were common (59\%), but only $2 \%$ were grade III or higher. Skin and subcutaneous tissue disorders occurred in $50 \%$ of patients with $12 \%$ being grade III or higher. Viral reactivation, lymphopenia, and neutropenia were other notable AEs.

While CCR4 mAbs have primarily been studied in T-cell NHL, it has been hypothesized that influencing the tumor microenvironment by halting Treg trafficking through CCR4 blockade may be broadly beneficial in many cancers [95-98].

\section{mAbs unblocking immune checkpoints}

While most mAbs in this category only indirectly target the lymphoma surface, they are included in this review as they exemplify the concept of active immunotherapy.

\section{PD-1/PD-L1 pathway}

Programmed cell death 1 (PD-1) is a negative costimulatory receptor critical for the suppression of T-cell activation. It is part of an immunoglobulin superfamily (B7) and expressed on T- and B-lymphocytes, natural killer (NK) cells, monocytes, and dendritic cells [99]. There are two PD-1 ligands: PD-1 ligand 1 (PD-L1/B7-H1) and PD-L2/B7-DC. The expression of PD-1 is significantly increased on CD4+ and CD8+ T cells following chronic exposure and stimulation with antigens related to infection or tumors [100].

On binding to its ligand, PD-1 generates a TCR-PD-1 microcluster [101], decreasing the phosphorylation of the multiple downstream signaling molecules (including Zap70, PI3K, and PKC- $\theta$ [102]) by recruiting SHP2, which in turn results in the attenuation of T-cell activation and so called "T-cell exhaustion". Blockade of the PDL-1/PD-L2 and PD-1 interaction was shown to render previously anergic T-cells responsive to antigen [103] (Figure 2). 


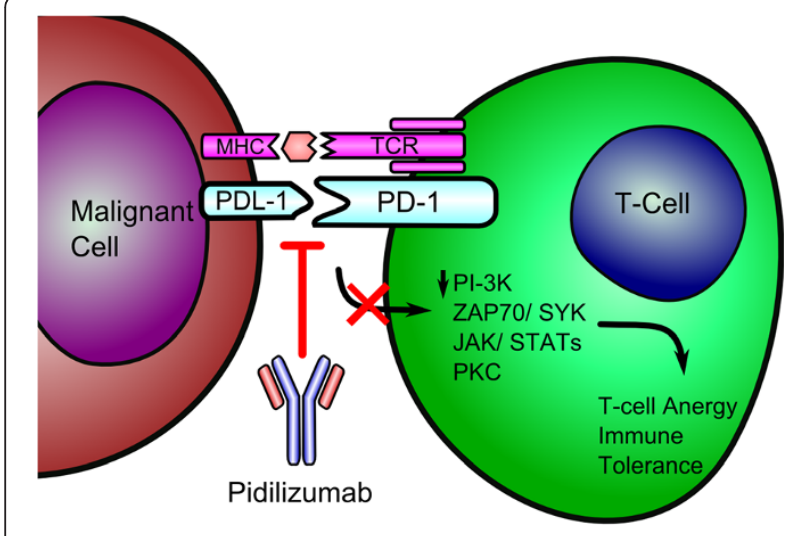

Figure 2 Mechanism of pidilizumab, which increases $\mathrm{T}$ cell activation and cytokine release by inhibiting co-inhibitory signaling up-regulated by tumors. Abbreviations: MHC Major Histocompatibility Complex; TCR, T-cell Receptor; PDL-1, Programmed Death Ligand 1; PD-1, Programmed Cell Death Protein 1.

Infiltration of anergic PD-1 positive T-cells has been demonstrated in lymphomas [104]. PD-L1 expression can be shown in a variety of B- and T-cell lymphomas [105-108]. Additionally, expression of PD-1 peripheral blood CD4+ and CD8+ lymphocytes has been described as markedly elevated in patients with lymphomas, including T-cell NHL, especially at the time of relapse [109].

\section{Pidilizumab}

Pidilizumab (formerly CT-011) is a humanized IgG-1א recombinant $\mathrm{mAb}$ that targets $\mathrm{PD} 1$. A phase 1 trial conducted by Berger et al. [110] enrolled 17 patients with advanced hematological malignancies including acute myeloid leukemia (AML), CLL, NHL, HL and multiple myeloma (MM). It concluded that CT-011 was safe and well tolerated, with clinical benefit observed in 33\%.

This was followed by a phase 2 international trial studying patients with DLBCL, primary mediastinal B-cell NHL or transformed indolent NHL, undergoing autologous stem cell transplant (ASCT) [111]. Patients received pidilizumab for three cycles, beginning 30 to 90 days after their ASCT. Among the 66 eligible patients, 16-month PFS was $72 \%$ while 16 -month OS was $85 \%$. No severe unexpected toxicities, significant autoimmune toxicities or treatment-related mortality was observed.

Another phase 2 study explored the efficacy of PD-1 blockade in combination with rituximab in relapsed rituximab-sensitive FL $(n=30)$ [112]. Pidilizumab was dosed every 4 weeks times four (additional doses for patients with SD or better) with weekly rituximab infusions times 4. Of 29 patients evaluable for activity, 19 (66\%) achieved an objective response. CR was identified in 15 (52\%) and PR in 4 (14\%) patients; median PFS was 18.8 months. The combination was well tolerated, with no severe autoimmune or treatment-related AEs.
Other mAbs targeting PD-1 or PD-L1 directly are under investigation. While it appears that PD-L1 expression on tumor cells is a necessary prerequisit [113], further research is needed to identify subsets of patients who most likely benefit from blockade of this axis. Potential biomarkers of response are tumor infiltrating lymphocytes, certain T-effector cell gene signatures or increased expression of PDL-1 in circulatory leucocytes [112].

Like PD-1, CTLA-4 is a negative regulator of T-cell activation that serves to dampen antitumor immune responses. Its ligand, B7-1, is found on APCs, B-cells and certain tumor cells. Blockade of CTLA- 4 has yielded increased T-cell mediated anti-tumor responses, most notably in metastatic melanoma [114]. Ipilimumab (Yervoy"), a CTLA-4 mAb, has been approved for treatment of metastatic melanoma. In a phase 1 trial ipilimumab was used to treat 18 patients with R/R DLBCL [115]. Responses were seen in 2 patients ( 1 with a CR lasting $>31$ months) and the drug was generally well tolerated, with diarrhea and fatigue as the only severe AE. Larger studies are ongoing to further explore the use of CTLA-4 blockade in hematological malignancies.

Unusual toxicities are a concern when unblocking immune checkpoints. Even though preliminary studies indicate that pidilizimab is well tolerated, studies involving other PD-1 inhibitors (e.g. nivolumab) and CTLA-4 mAbs have reported a myriad of AEs, including 3 treatmentrelated deaths reported with the use of nivolumab due

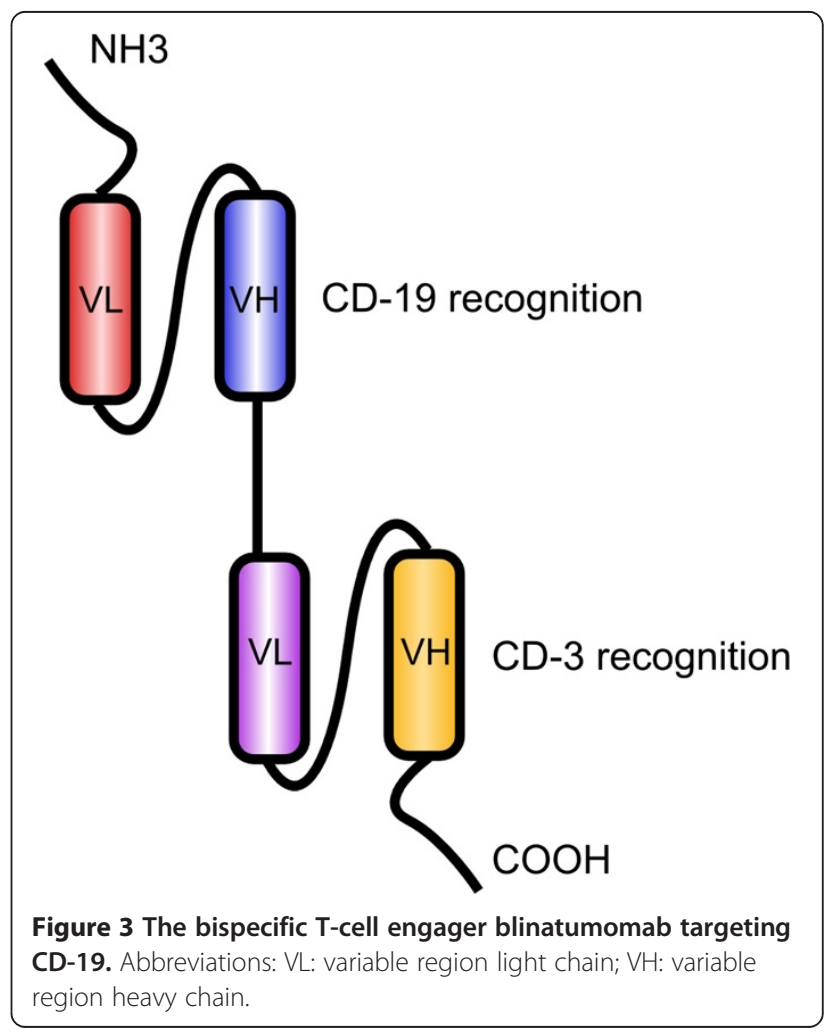


to pneumonitis. Common AEs include autoimmune disorders such as endocrinopathies (e.g. hypophysitis, hypothyroidism), skin disorders (e.g. rash, vitiligo), pneumonitis and colitis [116].

\section{Bispecific T-cell engagers (BiTE)}

BiTE molecules are engineered to contain the variable domains of two antibodies joined together: one antibody binds CD19 and one binds the CD3 antigen of T-cells. When bound to a CD3/CD19 complex, a BiTE brings the two cells in close proximity and thus activates T-cells to destroy the tumor cell via perforin-mediated apoptosis (Figure 3) [117].

\section{Blinatumomab}

Blinatumomab is a BiTE molecule that has been the forerunner of BiTE molecule testing and stands for B-lineage anti-tumoral $\mathrm{mAb}$. Promising activity has been demonstrated in patients with B-lineage ALL, specifically in MRD eradication [118-120].

The first phase 1 trial of blinatumomab as single agent given as continuous intravenous infusion in NHL began in 2004. The initial cohort of 38 patients had R/R B-cell NHL and received a continuous infusion at different doses for 4-8 weeks. Eleven patients (28.9\%) had measurable response after treatment; 4 (11\%) achieved a CR and $7(18 \%)$ a PR [121]. The trial established the maximum tolerated dose (MTD) of $60 \mu \mathrm{g} / \mathrm{m}^{2} / \mathrm{d}$. By 2011, the study had enrolled 62 patients. Of the 22 patients who received the MTD, 18 (82\%) showed an objective response and duration of response lasted up to 32 months.

Because of its clinical benefits and tolerability in indolent lymphomas, the study was expanded to include patients with DLBCL [122]. Twelve patients were enrolled with 9 patients evaluable for response. Five out of 9 patients (56\%) showed responses, the longest lasting 428 days. This set the stage for a phase 2 trial of blinatumomab in R/R DLBCL. Of the 11 patients recruited so far, 7 were evaluable for response: 3 patients experienced progression of disease, while 4 responded resulting in an ORR of $57 \%$ [120].

The most common clinical AEs regardless of grade included pyrexia, fatigue, headache, diarrhea, and weight increase. The dose-limiting factor was CNS related toxicity ranging from tremor, disorientation, speech disorder, cerebellar symptoms, to seizures.

While the results are intriguing, the optimal setting for blinatumomab in lymphomas remains to be defined. Multiple trials studying blinatumomab in B-cell malignancies are ongoing, the focus being B-lineage ALL.

\section{Conclusion}

Tremendous advances have been made in targeting the lymphoma surface. Initially only seen as a way to more precisely target tumors, actively harnessing the ability of the patients' own immune system in the fight against cancer is revolutionizing therapy. This involves rethinking current treatment paradigms in terms of response assessment [123] and side effect management. Unleashing the immune system can result in never-before encountered side effects. While results are promising, one remaining challenge is to identify which patient will respond to immunotherapy. Nevertheless, next to the classical modalities surgery, radiation, chemotherapy, and more recently molecularly targeted therapies, many regard immunotherapy now as the fifth pillar of oncology [124].

\section{Abbreviations}

mAB: Monoclonal antibodies; NHL: Non Hodgkin's lymphoma; ADCC: Antibody dependent cellular cytotoxicity; ADC: Antibody drug conjugates; RIT: Radioimmunotherapy; CaRs: Chimeric antigen receptors; BiTEs: Bispecific t-cell engagers; CDC: Complement dependent cytotoxicity; RR: Response rates; PFS: Progression free survival; CR: Complete response; ORR: Overall response rate; DLBCL: Diffuse large b-cell lymphoma; MCL: Mantle cell lymphoma; ADP: Antibody dependent phagocytosis; FCR: Fludaribine + cyclophosphamide + rituximab; O-FC: Fludarabine + cyclophosphamide; CIT: Chemoimmunotherapy; FL: Follicular lymphoma; R/R: Relapsed/refractory; Ig: Immunoglobulin; SLL: Small lymphocytic lymphoma; BCR: B-cell receptor; HL: Hodgkin's lymphoma; SD: Stable disease; MZ: Marginal zone lymphoma; TCL: T cell lymphomas; PTCL: Peripheral t cell lymphoma; TCL (CTCL): Advanced cutaneous; Treg: Regulatory t cells; ATLL: Adult T cell leukemia/ lymphoma; PD-1: Programmed cell death 1; NK: Natural killer; AML: Acute myeloid leukemia; MM: Multiple myeloma; ASCT: Autologous stem cell transplant.

\section{Competing interests}

Dr. Stefan Barta is part of the speakers bureau of Onyx, Celgene, and Janssen/ Pharmacyclics. He is on the advisory board of Seattle genetics and gets research funding from Otsuka.

\section{Authors' contributions}

All authors helped to draft and approved the manuscript.

\section{Authors' information}

SKB is an assistant professor of medicine and part of the lymphoma team at Fox Chase Cancer Center.

\section{Author details}

${ }^{1}$ Montefiore Medical Center/Albert-Einstein College of Medicine, Bronx, NY, USA. ${ }^{2}$ Fox Chase Cancer Center, Philadelphia, PA, USA.

Received: 4 June 2014 Accepted: 29 July 2014

Published online: 09 September 2014

\section{References}

1. McLaughlin P, Grillo-Lopez AJ, Link BK, Levy R, Czuczman MS, Williams ME, Heyman MR, Bence-Bruckler I, White CA, Cabanillas F, Jain V, Ho AD, Lister J, Wey K, Shen D, Dallaire BK: Rituximab chimeric anti-CD20 monoclonal antibody therapy for relapsed indolent lymphoma: half of patients respond to a four-dose treatment program. J Clin Oncol 1998, 16:2825-2833

2. Cheson BD, Leonard JP: Monoclonal antibody therapy for B-cell nonHodgkin's lymphoma. N Engl J Med 2008, 359:613-626.

3. Brody J, Kohrt H, Marabelle A, Levy R: Active and Passive Immunotherapy for Lymphoma: Proving Principles and Improving Results. J Clin Oncol 2011, 29:1864-1875.

4. Brentjens RJ, Curran KJ: Novel cellular therapies for leukemia: CARmodified T cells targeted to the CD19 antigen. Hematology Am Soc Hematol Educ Program 2012, 2012:143-151.

5. Feld J, Barta SK, Schinke C, Braunschweig I, Zhou Y, Verma AK: Linked-In: Design and Efficacy of Antibody Drug Conjugates in Oncology. Oncotarget 2013, 4(3):397-412. 
6. Tomblyn M: Radioimmunotherapy for B-cell non-hodgkin lymphomas. Cancer Control 2012, 19:196-203.

7. Kochenderfer JN, Rosenberg SA: Treating B-cell cancer with T cells expressing anti-CD19 chimeric antigen receptors. Nat Rev Clin Oncol 2013, 10:267-276.

8. Beers SA, Chan CH, French RR, Cragg MS, Glennie MJ: CD20 as a target for therapeutic type I and II monoclonal antibodies. Semin Hematol 2010, 47:107-114.

9. Cartron G, Dacheux L, Salles G, Solal-Celigny P, Bardos P, Colombat P, Watier $\mathrm{H}$ : Therapeutic activity of humanized anti-CD20 monoclonal antibody and polymorphism in IgG Fc receptor FcgammaRIlla gene. Blood 2002, 99:754-758.

10. Ghielmini M, Rufibach K, Salles G, Leoncini-Franscini L, Leger-Falandry C, Cogliatti S, Fey M, Martinelli G, Stahel R, Lohri A, Ketterer N, Wernli M, Cerny T, Schmitz SF: Single agent rituximab in patients with follicular or mantle cell lymphoma: clinical and biological factors that are predictive of response and event-free survival as well as the effect of rituximab on the immune system: a study of the Swiss Group for Clinical Cancer Research (SAKK). Ann Oncol 2005, 16:1675-1682.

11. Weng WK, Levy R: Two immunoglobulin $G$ fragment $C$ receptor polymorphisms independently predict response to rituximab in patients with follicular lymphoma. J ClinOncol 2003, 21:3940-3947.

12. Alduaij W, Ivanov A, Honeychurch J, Cheadle EJ, Potluri S, Lim SH, Shimada K, Chan CH, Tutt A, Beers SA, Glennie MJ, Cragg MS, Illidge TM: Novel type II anti-CD20 monoclonal antibody (GA101) evokes homotypic adhesion and actin-dependent, lysosome-mediated cell death in B-cell malignancies. Blood 2011, 117:4519-4529.

13. Chan HT, Hughes D, French RR, Tutt AL, Walshe CA, Teeling JL, Glennie MJ, Cragg MS: CD20-induced lymphoma cell death is independent of both caspases and its redistribution into triton X-100 insoluble membrane rafts. Cancer Res 2003, 63:5480-5489.

14. Cragg MS, Glennie MJ: Antibody specificity controls in vivo effector mechanisms of anti-CD20 reagents. Blood 2004, 103:2738-2743.

15. Glennie MJ, French RR, Cragg MS, Taylor RP: Mechanisms of killing by antiCD20 monoclonal antibodies. Mol Immunol 2007, 44:3823-3837.

16. Golay J, Da Roit F, Bologna L, Ferrara C, Leusen JH, Rambaldi A, Klein C, Introna M: Glycoengineered CD20 antibody obinutuzumab activates neutrophils and mediates phagocytosis through CD16B more efficiently than rituximab. Blood 2013, 122:3482-3491.

17. Mossner E, Brunker P, Moser S, Mossner E, Brunker P, Moser S, Puntener U, Schmidt C, Herter S, Grau R, Gerdes C, Nopora A, van Puijenbroek E, Ferrara C, Sondermann P, Jager C, Strein P, Fertig G, Friess T, Schull C, Bauer S, Dal Porto J, Del Nagro C, Dabbagh K, Dyer MJ, Poppema S, Klein C, Umana P: Increasing the efficacy of CD20 antibody therapy through the engineering of a new type II anti-CD20 antibody with enhanced direct and immune effector cellmediated B-cell cytotoxicity. Blood 2010, 115:4393-4402.

18. Cartron G, Watier H, Golay J, Solal-Celigny P: From the bench to the bedside: ways to improve rituximab efficacy. Blood 2004, 104:2635-2642.

19. Wang SY, Racila E, Taylor RP, Weiner GJ: NK-cell activation and antibodydependent cellular cytotoxicity induced by rituximab-coated target cells is inhibited by the C3b component of complement. Blood 2008, 111:1456-1463.

20. Beers SA, French RR, Chan HT, Lim SH, Jarrett TC, Vidal RM, Wijayaweera SS, Dixon SV, Kim H, Cox KL, Kerr JP, Johnston DA, Johnson PW, Verbeek JS, Glennie MJ, Cragg MS: Antigenic modulation limits the efficacy of antiCD20 antibodies: implications for antibody selection. Blood 2010, 115:5191-5201.

21. Goede V, Fischer K, Busch R, Engelke A, Eichhorst B, Wendtner CM, Chagorova T, de la Serna J, Dilhuydy MS, IIImer T, Opat S, Owen CJ, Samoylova O, Kreuzer KA, Stilgenbauer S, Dohner H, Langerak AW, Ritgen M, Kneba M, Asikanius E, Humphrey K, Wenger M, Hallek M: Obinutuzumab plus chlorambucil in patients with CLL and coexisting conditions. N Engl J Med 2014, 370:1101-1110.

22. Radford J, Davies A, Cartron G, Morschhauser F, Salles G, Marcus R, Wenger M, Lei G, Wassner-Fritsch E, Vitolo U: Obinutuzumab (GA101) plus CHOP or FC in relapsed/refractory follicular lymphoma: results of the GAUDI study (BO21000). Blood 2013, 122:1137-1143.

23. Morschhauser FA, Cartron G, Thieblemont C, Solal-Celigny P, Haioun C, Bouabdallah R, Feugier P, Bouabdallah $K$, Asikanius E, Lei G, Wenger M, Wassner-Fritsch E, Salles GA: Obinutuzumab (GA101) monotherapy in relapsed/refractory diffuse large b-cell lymphoma or mantle-cell lymphoma: results from the phase II GAUGUIN study. J Clin Oncol 2013, 31:2912-2919

24. Teeling $J$, Mackus WJ, Wiegman $L J$, van den Brakel $J H$, Beers SA, French RR, van Meerten T, Ebeling S, Vink T, Slootstra JW, Parren PW, Glennie MJ, van de Winkel JG: The biological activity of human CD20 monoclonal antibodies is linked to unique epitopes on CD20. J Immunol 2006, 177:362-371.

25. Rafiq S, Butchar JP, Cheney C, Mo X, Trotta R, Caligiuri M, Jarjoura D, Tridandapani S, Muthusamy N, Byrd JC: Comparative assessment of clinically utilized CD20-directed antibodies in chronic lymphocytic leukemia cells reveals divergent NK cell, monocyte, and macrophage properties. J Immunol 2013, 190:2702-2711.

26. Wierda WG, Kipps TJ, Mayer J, Padmanabhan S, Chan GW, Gupta IV, Lisby S, Osterborg A: Ofatumumab as single-agent CD20 immunotherapy in fludarabine-refractory chronic lymphocytic leukemia. J Clin Oncol 2010, 28:1749-1755.

27. Wierda WG, Padmanabhan S, Chan GW, Gupta IV, Lisby S, Osterborg A Ofatumumab is active in patients with fludarabine-refractory CLL irrespective of prior rituximab: results from the phase 2 international study. Blood 2011, 118:5126-5129.

28. Shanafelt T, Lanasa MC, Call TG, Beaven AW, Leis JF, Laplant B, Bowen D, Conte M, Jelinek DF, Hanson CA, Kay NE, Zent CS: Ofatumumab-based chemoimmunotherapy is effective and well tolerated in patients with previously untreated chronic lymphocytic leukemia (CLL). Cancer 2013, 119:3788-3796.

29. Kay NE, Geyer SM, Call TG, Shanafelt TD, Zent CS, Jelinek DF, Tschumper R, Bone ND, Dewald GW, Lin TS, Heerema NA, Smith L, Grever MR, Byrd JC: Combination chemoimmunotherapy with pentostatin, cyclophosphamide, and rituximab shows significant clinical activity with low accompanying toxicity in previously untreated B chronic lymphocytic leukemia. Blood 2007, 109:405-411.

30. Hallek M, Fingerle-Rowson G, Fink AM, Busch R, Mayer J, Hensel M, Hopfinger G, Hess G, von Grunhagen U, Bergmann M, Catalano J, Zinzani PL, Caligaris-Cappio F, Seymour JF, Berrebi A, Jager U, Cazin B, Trneny M, Westermann A, Wendtner CM, Eichhorst BF, Staib P, Buhler A, Winkler D, Zenz T, Bottcher S, Ritgen M, Mendila M, Kneba M, Dohner H, et al: Addition of rituximab to fludarabine and cyclophosphamide in patients with chronic lymphocytic leukaemia: a randomised, open-label, phase 3 trial. Lancet 2010, 376:1164-1174

31. Wierda WG, Kipps TJ, Durig J, Griskevicius L, Stilgenbauer S, Mayer J, Smolej L, Hess G, Griniute R, Hernandez-llizaliturri FJ, Padmanabhan S, Gorczyca M, Chang CN, Chan G, Gupta I, Nielsen TG, Russell CA: Chemoimmunotherapy with O-FC in previously untreated patients with chronic lymphocytic leukemia. Blood 2011, 117:6450-6458.

32. Czuczman MS, Fayad L, Delwail V, Cartron G, Jacobsen E, Kuliczkowski K, Link BK, Pinter-Brown L, Radford J, Hellmann A, Gallop-Evans E, DiRienzo CG, Goldstein N, Gupta I, Jewell RC, Lin TS, Lisby S, Schultz M, Russell CA, Hagenbeek $A$ : Chemoimmunotherapy with ofatumumab in combination with CHOP in previously untreated follicular lymphoma. Br J Haematol 2012, 157:438-445.

33. Czuczman MS, Fayad L, Delwail V, Cartron G, Jacobsen E, Kuliczkowski K, Link BK, Pinter-Brown L, Radford J, Hellmann A, Gallop-Evans E, DiRienzo CG, Goldstein N, Gupta I, Jewell RC, Lin TS, Lisby S, Schultz M, Russell CA Hagenbeek A: Ofatumumab monotherapy in rituximab-refractory follicular lymphoma: results from a multicenter study. Blood 2012, 119:3698-3704.

34. Coiffier B, Radford J, Bosly A, Martinelli G, Barca G, Davies A, Decaudin D, Gallop-Evans E, Padmanabhan-lyer S, Van Eygen K, Wu KL, Gupta IV, Lin TS, Goldstein N, Jewell RC, Winter P, Lisby S: A multicentre, phase II trial of ofatumumab monotherapy in relapsed/progressive diffuse large B-cell lymphoma. Br J Haematol 2013, 163:334-342.

35. Matasar MJ, Czuczman MS, Rodriguez MA, Fennessy M, Shea TC, Spitzer G, Lossos IS, Kharfan-Dabaja MA, Joyce R, Fayad L, Henkel K, Liao Q, Edvardsen K, Jewell RC, Fecteau D, Singh RP, Lisby S, Moskowitz CH: Ofatumumab in combination with ICE or DHAP chemotherapy in relapsed or refractory intermediate grade B-cell lymphoma. Blood 2013, 122:499-506.

36. Goldenberg DM, Rossi EA, Stein R, Goldenberg DM, Rossi EA, Stein R, Cardillo TM, Czuczman MS, Hernandez-llizaliturri FJ, Hansen HJ, Chang CH: Properties and structure-function relationships of veltuzumab (hA20), a humanized anti-CD20 monoclonal antibody. Blood 2009, 113:1062-1070. 
37. Morschhauser F, Leonard JP, Fayad L, Coiffier B, Petillon MO, Coleman M, Schuster SJ, Dyer MJ, Horne H, Teoh N, Wegener WA, Goldenberg DM: Humanized anti-CD20 antibody, veltuzumab, in refractory/recurrent nonHodgkin's lymphoma: phase I/II results. J Clin Oncol 2009, 27:3346-3353.

38. Negrea GO, Elstrom R, Allen SL, Rai KR, Abbasi RM, Farber CM, Teoh N, Horne H, Wegener WA, Goldenberg DM: Subcutaneous injections of lowdose veltuzumab (humanized anti-CD20 antibody) are safe and active in patients with indolent non-Hodgkin's lymphoma. Haematologica 2011 96:567-573.

39. Morschhauser F, Marlton P, Vitolo U, Linden O, Seymour JF, Crump M, Coiffier B, Foa R, Wassner E, Burger HU, Brennan B, Mendila M: Results of a phase I/II study of ocrelizumab, a fully humanized anti-CD20 mAb, in patients with relapsed/refractory follicular lymphoma. Ann Oncol 2010, 21:1870-1876

40. Tobinai K, Ogura M, Kobayashi $Y$, Uchida T, Watanabe T, Oyama T, Maruyama D, Suzuki T, Mori M, Kasai M, Cronier D, Wooldridge JE, Koshiji M: Phase I study of LY2469298, an Fc-engineered humanized anti-CD20 antibody, in patients with relapsed or refractory follicular lymphoma. Cancer Sci 2011, 102:432-438.

41. Forero-Torres A, de Vos S, Pohlman BL, Pashkevich M, Cronier DM, Dang NH, Carpenter SP, Allan BW, Nelson JG, Slapak CA, Smith MR, Link BK, Wooldridge JE, Ganjoo KN: Results of a phase 1 study of AME-133v (LY2469298), an Fcengineered humanized monoclonal anti-CD20 antibody, in FcgammaRIllagenotyped patients with previously treated follicular lymphoma. Clin Cancer Res 2012, 18:1395-1403.

42. Kobayashi H, Matsunaga Y, Uchiyama Y, Nagura K, Komatsu Y: Novel humanized anti-CD20 antibody BM-ca binds to a unique epitope and exerts stronger cellular activity than others. Cancer Med 2013, 2:130-143.

43. Uchiyama S, Suzuki Y, Otake K, Yokoyama M, Ohta M, Aikawa S, Komatsu M, Sawada T, Kagami Y, Morishima Y, Fukui K: Development of novel humanized anti-CD20 antibodies based on affinity constant and epitope. Cancer Sci 2010, 101:201-209.

44. Kensei Tobinai MO, Dai M, Tatsuya S, Yukio K, Toshiki U, Suguru F, Takashi O, Tomoharu F, Yasuhiko K, National Cancer Center Hospital, Tokyo, Japan; Nagoya Daini Red Cross Hospital, Nagoya, Japan; BioMedics Japan Inc., Tokyo, Japan: Phase I study of a novel humanized anti-CD20 antibody, $\mathrm{BM}-\mathrm{ca}$, in patients (pts) with relapsed or refractory indolent B cell non-Hodgkin lymphoma (B-NHL) pretreated with rituximab. 2013 ASCO Annual Meeting; 2013. J Clin Oncol 2013, 31(suppl; abstr 8551).

45. Daridon C, Blassfeld D, Reiter K, Mei HE, Giesecke C, Goldenberg DM, Hansen A, Hostmann A, Frolich D, Dorner T: Epratuzumab targeting of CD22 affects adhesion molecule expression and migration of B-cells in systemic lupus erythematosus. Arthritis Res Ther 2010, 12:R204.

46. Kreitman RJ, Pastan I: Antibody fusion proteins: anti-CD22 recombinant immunotoxin moxetumomab pasudotox. Clin Cancer Res 2011, 17:6398-6405

47. Tedder TF, Tuscano J, Sato S, Kehrl JH: CD22, a B lymphocyte-specific adhesion molecule that regulates antigen receptor signaling. Annu Rev Immunol 1997, 15:481-504.

48. Shan D, Press OW: Constitutive endocytosis and degradation of CD22 by human B cells. J Immunol 1995, 154:4466-4475.

49. Shih $L B, L u H H$, Xuan $H$, Goldenberg DM: Internalization and intracellular processing of an anti-B-cell lymphoma monoclonal antibody, LL2. Int J Cancer 1994, 56:538-545.

50. Micallef IN, Maurer MJ, Wiseman GA, Nikcevich DA, Kurtin PJ, Cannon MW, Perez DG, Soori GS, Link BK, Habermann TM, Witzig TE: Epratuzumab with rituximab, cyclophosphamide, doxorubicin, vincristine, and prednisone chemotherapy in patients with previously untreated diffuse large B-cell lymphoma. Blood 2011, 118:4053-4061.

51. Leonard JP, Coleman M, Ketas JC, Chadburn A, Ely S, Furman RR, Wegener WA Hansen HJ, Ziccardi H, Eschenberg M, Gayko U, Cesano A, Goldenberg DM: Phase I/II trial of epratuzumab (humanized anti-CD22 antibody) in indolent non-Hodgkin's lymphoma. J Clin Oncol 2003, 21:3051-3059.

52. Leonard JP, Coleman M, Ketas JC, Chadburn A, Furman R, Schuster MW, Feldman EJ, Ashe M, Schuster SJ, Wegener WA, Hansen HJ, Ziccardi H, Eschenberg M, Gayko U, Fields SZ, Cesano A, Goldenberg DM: Epratuzumab, a humanized anti-CD22 antibody, in aggressive nonHodgkin's lymphoma: phase I/II clinical trial results. Clin Cancer Res 2004, 10:5327-5334.

53. Strauss SJ, Morschhauser F, Rech J, Repp R, Solal-Celigny P, Zinzani PL, Engert A, Coiffier B, Hoelzer DF, Wegener WA, Teoh NK, Goldenberg DM,
Lister TA: Multicenter phase II trial of immunotherapy with the humanized anti-CD22 antibody, epratuzumab, in combination with rituximab, in refractory or recurrent non-Hodgkin's lymphoma. J Clin Oncol 2006, 24:3880-3886.

54. Leonard JP, Schuster SJ, Emmanouilides C, Couture F, Teoh N, Wegener WA, Coleman M, Goldenberg DM: Durable complete responses from therapy with combined epratuzumab and rituximab: final results from an international multicenter, phase 2 study in recurrent, indolent, nonHodgkin lymphoma. Cancer 2008, 113:2714-2723.

55. Grant BW, Jung SH, Johnson JL, Kostakoglu L, Hsi E, Byrd JC, Jones J, Leonard JP, Martin SE, Cheson BD: A phase 2 trial of extended induction epratuzumab and rituximab for previously untreated follicular lymphoma: CALGB 50701. Cancer 2013, 119:3797-3804.

56. Cesano A, Gayko U: CD22 as a target of passive immunotherapy. Semin Oncol 2003, 30:253-257.

57. Carter RH, Myers R: Germinal center structure and function: lessons from CD19. Semin Immunol 2008, 20:43-48.

58. Tedder TF: CD19: a promising B cell target for rheumatoid arthritis. Nat Rev Rheumatol 2009, 5:572-577.

59. Tedder TF, Inaoki M, Sato S: The CD19-CD21 complex regulates signal transduction thresholds governing humoral immunity and autoimmunity. Immunity 1997, 6:107-118.

60. Herbst R, Wang Y, Gallagher S, Mittereder N, Kuta E, Damschroder M, Woods R, Rowe DC, Cheng L, Cook K, Evans K, Sims GP, Pfarr DS, Bowen MA, Dall'Acqua W, Shlomchik M, Tedder TF, Kiener P, Jallal B, Wu H, Coyle AJ: B-cell depletion in vitro and in vivo with an afucosylated anti-CD19 antibody. J Pharmacol Exp Ther 2010, 335:213-222.

61. Hamadani M, Fanale MA, Bello CM, Kipps TJ, Offner F, Verhoef G, Federico M, Gregory SA, Sonet A, Assouline S, Pérez De Oteyza J, Tomas JF, Cuneo A, Elgeioushi N, Goswami T, Ibrahim R, Herbst R, Cheson BD: Safety Profile and Clinical Response To MEDI-551, a Humanized Monoclonal AntiCD19, In a Phase 1/2 Study In Adults With Relapsed Or Refractory Advanced B-Cell Malignancies. Blood 2013, 122:1810.

62. Carbone A, Gloghini A, Zagonel V, Aldinucci D, Gattei V, Degan M, Improta S, Sorio R, Monfardini S, Pinto A: The expression of CD26 and CD40 ligand is mutually exclusive in human T-cell non-Hodgkin's lymphomas/leukemias. Blood 1995, 86:4617-4626.

63. Gruss HJ, Dower SK: Tumor necrosis factor ligand superfamily: involvement in the pathology of malignant lymphomas. Blood 1995, 85:3378-3404

64. Luqman M, Klabunde S, Lin K, Georgakis GV, Cherukuri A, Holash J, Goldbeck C, Xu X, Kadel EE 3rd, Lee SH, Aukerman SL, Jallal B, Aziz N, Weng WK, Wierda W, O'Brien S, Younes A: The antileukemia activity of a human anti-CD40 antagonist antibody, HCD122, on human chronic lymphocytic leukemia cells. Blood 2008, 112:711-720.

65. Uckun FM, Gajl-Peczalska K, Myers DE, Jaszcz W, Haissig S, Ledbetter JA: Temporal association of CD40 antigen expression with discrete stages of human B-cell ontogeny and the efficacy of anti-CD40 immunotoxins against clonogenic B-lineage acute lymphoblastic leukemia as well as B-lineage non-Hodgkin's lymphoma cells. Blood 1990, 76:2449-2456.

66. Aldinucci D, Gloghini A, Pinto A, Colombatti A, Carbone A: The role of CD40/CD40L and interferon regulatory factor 4 in Hodgkin lymphoma microenvironment. Leuk Lymphoma 2012, 53:195-201.

67. Rydstrom K, Linderoth J, Nyman H, Ehinger M, Joost P, Bendahl PO, Leppa S, Jerkeman M: CD40 is a potential marker of favorable prognosis in patients with diffuse large B-cell lymphoma treated with immunochemotherapy. Leuk Lymphoma 2010, 51:1643-1648.

68. Franco G, Guarnotta C, Frossi B, Piccaluga PP, Boveri E, Gulino A, Fuligni F, Rigoni A, Porcasi R, Buffa S, Betto E, Florena AM, Franco V, lannitto E, Arcaini L, Pileri SA, Pucillo C, Colombo MP, Sangaletti S, Tripodo C: Bone marrow stroma CD40 expression correlates with inflammatory mast cell infiltration and disease progression in splenic marginal zone lymphoma. Blood 2014, 123:1836-1849.

69. Byrd JC, Kipps TJ, Flinn IW, Cooper M, Odenike O, Bendiske J, Rediske J, Bilic S, Dey J, Baeck J, O'Brien S: Phase I study of the anti-CD40 humanized monoclonal antibody lucatumumab (HCD122) in relapsed chronic lymphocytic leukemia. Leuk Lymphoma 2012, 53:2136-2142.

70. Fanale M, Assouline S, Kuruvilla J, Solal-Celigny P, Heo DS, Verhoef G, Corradini P, Abramson JS, Offner F, Engert A, Dyer MJ, Carreon D, Ewald B, Baeck J, Younes A, Freedman AS: Phase IA/II, multicentre, 
open-label study of the CD40 antagonistic monoclonal antibody lucatumumab in adult patients with advanced non-Hodgkin or Hodgkin lymphoma. Br J Haematol 2014, 164:258-265.

71. Law CL, Gordon KA, Collier J, Klussman K, McEarchern JA, Cerveny CG, Mixan BJ, Lee WP, Lin Z, Valdez P, Wahl AF, Grewal IS: Preclinical antilymphoma activity of a humanized anti-CD40 monoclonal antibody, SGN-40. Cancer Res 2005, 65:8331-8338.

72. Lewis TS, McCormick RS, Emmerton K, Lau JT, Yu SF, McEarchern JA, Grewal IS, Law CL: Distinct apoptotic signaling characteristics of the anti-CD40 monoclonal antibody dacetuzumab and rituximab produce enhanced antitumor activity in non-Hodgkin lymphoma. Clin Cancer Res 2011, 17:4672-4681.

73. Advani R, Forero-Torres A, Furman RR, Rosenblatt JD, Younes A, Ren $H$, Harrop K, Whiting N, Drachman JG: Phase I study of the humanized anti-CD40 monoclonal antibody dacetuzumab in refractory or recurrent non-Hodgkin's lymphoma. J Clin Oncol 2009, 27:4371-4377.

74. Furman RR, Forero-Torres A, Shustov A, Drachman JG: A phase I study of dacetuzumab (SGN-40, a humanized anti-CD40 monoclonal antibody) in patients with chronic lymphocytic leukemia. Leuk Lymphoma 2010 51:228-235

75. Forero-Torres A, Bartlett N, Beaven A, Myint H, Nasta S, Northfelt DW Whiting NC, Drachman JG, Lobuglio AF, Moskowitz CH: Pilot study of dacetuzumab in combination with rituximab and gemcitabine for relapsed or refractory diffuse large B-cell lymphoma. Leuk Lymphoma 2013, 54:277-283.

76. Lopez A, Gutierrez A, Palacios A, Blancas I, Navarrete M, Morey M, Perello A Alarcon J, Martinez J, Rodriguez J: GEMOX-R regimen is a highly effective salvage regimen in patients with refractory/relapsing diffuse large-cell lymphoma: a phase II study. Eur J Haematol 2008, 80:127-132.

77. Rossmann ED, Lundin J, Lenkei R, Mellstedt H, Osterborg A: Variability in B-cell antigen expression: implications for the treatment of B-cell lymphomas and leukemias with monoclonal antibodies. Hematol J 2001, 2:300-306.

78. Mone AP, Cheney C, Banks AL, Tridandapani S, Mehter N, Guster S, Lin T, Eisenbeis CF, Young DC, Byrd JC: Alemtuzumab induces caspaseindependent cell death in human chronic lymphocytic leukemia cells through a lipid raft-dependent mechanism. Leukemia 2006, 20:272-279

79. Riechmann L, Clark M, Waldmann H, Winter G: Reshaping human antibodies for therapy. Nature 1988, 332:323-327.

80. Xia MQ, Hale G, Waldmann H: Efficient complement-mediated lysis of cells containing the CAMPATH-1 (CDw52) antigen. Mol Immunol 1993, 30:1089-1096.

81. Demko S, Summers J, Keegan P, Pazdur R: FDA drug approval summary: alemtuzumab as single-agent treatment for B-cell chronic lymphocytic leukemia. Oncologist 2008, 13:167-174.

82. Hillmen P, Skotnicki AB, Robak T, Jaksic B, Dmoszynska A, Wu J, Sirard C, Mayer J: Alemtuzumab compared with chlorambucil as first-line therapy for chronic lymphocytic leukemia. J Clin Oncol 2007, 25:5616-5623.

83. Osterborg A, Foa R, Bezares RF, Dearden C, Dyer MJ, Geisler C, Lin TS, Montillo M, van Oers MH, Wendtner CM, Rai KR: Management guidelines for the use of alemtuzumab in chronic lymphocytic leukemia. Leukemia 2009, 23:1980-1988

84. Enblad G, Hagberg H, Erlanson M, Lundin J, MacDonald AP, Repp R, Schetelig J, Seipelt G, Osterborg A: A pilot study of alemtuzumab (anti-CD52 monoclonal antibody) therapy for patients with relapsed or chemotherapy-refractory peripheral T-cell lymphomas. Blood 2004, 103:2920-2924.

85. Gallamini A, Zaja F, Patti C, Billio A, Specchia MR, Tucci A, Levis A, Manna A, Secondo V, Rigacci L, Pinto A, lannitto E, Zoli V, Torchio P, Pileri S, Tarella C: Alemtuzumab (Campath-1H) and CHOP chemotherapy as first-line treatment of peripheral T-cell lymphoma: results of a GITIL (Gruppo Italiano Terapie Innovative nei Linfomi) prospective multicenter trial. Blood 2007, 110:2316-2323.

86. Lundin J, Hagberg H, Repp R, Cavallin-Stahl E, Freden S, Juliusson G, Rosenblad E, Tjonnfjord G, Wiklund T, Osterborg A: Phase 2 study of alemtuzumab (anti-CD52 monoclonal antibody) in patients with advanced mycosis fungoides/Sezary syndrome. Blood 2003, 101:4267-4272.

87. Gritti G, Reda G, Maura F, Piciocchi A, Baldini L, Molica S, Neri A, Cortelezzi A: Low dose alemtuzumab in patients with fludarabine-refractory chronic lymphocytic leukemia. Leuk Lymphoma 2012, 53:424-429.
88. Brown JR, Messmer B, Werner L, Davids MS, Mikler E, Supko JG, Fisher DC, LaCasce AS, Armand P, Jacobsen E, Dalton V, Tesar B, Fernandes SM, McDonough S, Ritz J, Rassenti L, Kipps TJ, Neuberg D, Freedman AS: A phase I study of escalated dose subcutaneous alemtuzumab given weekly with rituximab in relapsed chronic lymphocytic leukemia/small lymphocytic lymphoma. Haematologica 2013, 98:964-970.

89. Binder C, Ziepert M, Pfreundschuh M, Duhrsen U, Eimermacher $H$, Aldaoud A, Rosenwald A, Loeffler M, Schmitz N, Truemper L: CHO(E)P-14 followed by alemtuzumab consolidation in untreated peripheral T cell lymphomas: final analysis of a prospective phase II trial. Ann Hematol 2013, 92:1521-1528.

90. Ishida T, Ueda R: CCR4 as a novel molecular target for immunotherapy of cancer. Cancer Sci 2006, 97:1139-1146.

91. Yamamoto K, Utsunomiya A, Tobinai K, Tsukasaki K, Uike N, Uozumi K, Yamaguchi K, Yamada Y, Hanada S, Tamura K, Nakamura S, Inagaki H, Ohshima K, Kiyoi H, Ishida T, Matsushima K, Akinaga S, Ogura M, Tomonaga M, Ueda R: Phase I study of KW-0761, a defucosylated humanized anti-CCR4 antibody, in relapsed patients with adult T-cell leukemia-lymphoma and peripheral T-cell lymphoma. J Clin Oncol 2010, 28:1591-1598.

92. Ishida T, Joh T, Uike N, Yamamoto K, Utsunomiya A, Yoshida S, Saburi Y, Miyamoto T, Takemoto S, Suzushima H, Tsukasaki K, Nosaka K, Fujiwara H, Ishitsuka K, Inagaki H, Ogura M, Akinaga S, Tomonaga M, Tobinai K, Ueda R: Defucosylated anti-CCR4 monoclonal antibody (KW-0761) for relapsed adult T-cell leukemia-lymphoma: a multicenter phase II study. J Clin Oncol 2012, 30:837-842.

93. Kim Y, Pinter-Brown L, Foss F, Sokol L, Jorgensen J, Spitalny G, Duvic M: CO26. Results of a phase $1 / 2$ study for KW-0761, a monoclonal antibody directed against CC chemokine receptor type 4 (CCR4), in CTCL patients. Melanoma Res 2011, 21:e15-e16.

94. Ogura M, Ishida T, Hatake K, Taniwaki M, Ando K, Tobinai K, Fujimoto K, Yamamoto K, Miyamoto T, Uike N, Tanimoto M, Tsukasaki K, Ishizawa K, Suzumiya J, Inagaki H, Tamura K, Akinaga S, Tomonaga M, Ueda R: Multicenter phase II study of mogamulizumab (KW-0761), a defucosylated anti-cc chemokine receptor 4 antibody, in patients with relapsed peripheral T-cell lymphoma and cutaneous T-cell lymphoma. J Clin Oncol 2014, 32:1157-1163.

95. Curiel TJ, Coukos G, Zou L, Alvarez X, Cheng P, Mottram P, Evdemon-Hogan M, Conejo-Garcia JR, Zhang L, Burow M: Specific recruitment of regulatory T cells in ovarian carcinoma fosters immune privilege and predicts reduced survival. Nat Med 2004, 10:942-949.

96. Strauss L, Bergmann C, Szczepanski M, Gooding W, Johnson JT, Whiteside TL: A unique subset of CD4+ CD25highFoxp3+ T cells secreting interleukin-10 and transforming growth factor- $\beta 1$ mediates suppression in the tumor microenvironment. Clin Cancer Res 2007, 13:4345-4354.

97. Mizukami Y, Kono K, Kawaguchi Y, Akaike H, Kamimura K, Sugai H, Fujii H: CCL17 and CCL22 chemokines within tumor microenvironment are related to accumulation of Foxp3+ regulatory T cells in gastric cancer. Int J Cancer 2008, 122:2286-2293.

98. Gobert M, Treilleux I, Bendriss-Vermare N, Bachelot T, Goddard-Leon S, Arfi V, Biota C, Doffin AC, Durand I, Olive D: Regulatory T cells recruited through CCL22/CCR4 are selectively activated in lymphoid infiltrates surrounding primary breast tumors and lead to an adverse clinical outcome. Cancer Res 2009, 69:2000-2009.

99. Keir ME, Butte MJ, Freeman GJ, Sharpe AH: PD-1 and its ligands in tolerance and immunity. Annu Rev Immunol 2008, 26:677-704.

100. Agata Y, Kawasaki A, Nishimura H, Ishida Y, Tsubata T, Yagita H, Honjo T: Expression of the PD-1 antigen on the surface of stimulated mouse $T$ and B lymphocytes. Int Immunol 1996, 8:765-772.

101. Yokosuka T, Takamatsu M, Kobayashi-Imanishi W, Hashimoto-Tane A Azuma M, Saito T: Programmed cell death 1 forms negative costimulatory microclusters that directly inhibit T cell receptor signaling by recruiting phosphatase SHP2. J Exp Med 2012, 209:1201-1217.

102. Sheppard KA, Fitz LJ, Lee JM, Benander C, George JA, Wooters J, Qiu Y, Jussif JM, Carter LL, Wood CR, Chaudhary D: PD-1 inhibits T-cell receptor induced phosphorylation of the ZAP70/CD3zeta signalosome and downstream signaling to PKCtheta. FEBS Lett 2004, 574:37-41

103. Tsushima F, Yao S, Shin T, Flies A, Flies S, Xu H, Tamada K, Pardoll DM, Chen L: Interaction between B7-H1 and PD-1 determines initiation and reversal of T-cell anergy. Blood 2007, 110:180-185. 
104. Myklebust JH, Irish JM, Brody J, Czerwinski DK, Houot R, Kohrt HE, Timmerman J, Said J, Green MR, Delabie J, Kolstad A, Alizadeh AA, Levy R: High PD-1 expression and suppressed cytokine signaling distinguish T cells infiltrating follicular lymphoma tumors from peripheral T cells. Blood 2013, 121:1367-1376

105. Chen BJ, Chapuy B, Ouyang J, Sun HH, Roemer MG, Xu ML, Yu H, Fletcher CD, Freeman GJ, Shipp MA, Rodig SJ: PD-L1 expression is characteristic of a subset of aggressive B-cell lymphomas and virus-associated malignancies. Clin Cancer Res 2013, 19:3462-3473.

106. Kozako T, Yoshimitsu M, Fujiwara H, Masamoto I, Horai S, White Y, Akimoto M, Suzuki S, Matsushita K, Uozumi K, Tei C, Arima N: PD-1/PD-L1 expression in human T-cell leukemia virus type 1 carriers and adult T-cell leukemia/ lymphoma patients. Leukemia 2009, 23:375-382

107. Andorsky DJ, Yamada RE, Said J, Pinkus GS, Betting DJ, Timmerman JM: Programmed death ligand 1 is expressed by non-hodgkin lymphomas and inhibits the activity of tumor-associated T cells. Clin Cancer Res 2011 17:4232-4244

108. Munir S, Andersen GH, Woetmann A, Odum N, Becker JC, Andersen MH: Cutaneous $T$ cell lymphoma cells are targets for immune checkpoint ligand PD-L1-specific, cytotoxic T cells. Leukemia 2013, 27:2251-2253.

109. Prochazka V, Novak M, Pikalova Z, Papajik T, Indrak K, Divoky V: Number of PD-1+/CD8+ Cells in Peripheral Blood of Patients with Lymphoma Reflects Tumor Burden, Lymphoma Subtype, Disease Phase and Is Significantly Higher Compared to Healthy Volunteers. ASH Annu Meet Abstr 2012, 120:2670.

110. Berger R, Rotem-Yehudar R, Slama G: Phase I safety and pharmacokinetic study of CT-011, a humanized antibody interacting with PD-1, in patients with advanced hematologic malignancies. Clin Cancer Res 2008 14:3044-3051

111. Armand $P$, Nagler A, Weller EA, Devine SM, Avigan DE, Chen YB, Kaminski MS, Holland HK, Winter JN, Mason JR, Fay JW, Rizzieri DA, Hosing CM, Ball ED, Uberti JP, Lazarus HM, Mapara MY, Gregory SA, Timmerman JM, Andorsky D, Or R, Waller EK, Rotem-Yehudar R, Gordon LI: Disabling immune tolerance by programmed death-1 blockade with pidilizumab after autologous hematopoietic stem-cell transplantation for diffuse large B-cell lymphoma: results of an international phase II trial. J Clin Oncol 2013, 31:4199-4206.

112. Westin JR, Chu F, Zhang M, Fayad LE, Kwak LW, Fowler N, Romaguera J, Hagemeister F, Fanale M, Samaniego F, Feng L, Baladandayuthapani V Wang Z, Ma W, Gao Y, Wallace M, Vence LM, Radvanyi L, Muzzafar T, Rotem-Yehudar R, Davis RE, Neelapu SS: Safety and activity of PD1 blockade by pidilizumab in combination with rituximab in patients with relapsed follicular lymphoma: a single group, open-label, phase 2 trial. Lancet Oncol 2014, 15:69-77.

113. Topalian SL, Sznol M, McDermott DF, Kluger HM, Carvajal RD, Sharfman WH, Brahmer JR, Lawrence DP, Atkins MB, Powderly JD, Leming PD, Lipson EJ, Puzanov I, Smith DC, Taube JM, Wigginton JM, Kollia GD, Gupta A, Pardoll DM, Sosman JA, Hodi FS: Safety, Activity, and Immune Correlates of Anti-PD-1 Antibody in Cancer. N Engl J Med 2012, 366:2443-2454.

114. Topalian SL, Sznol M, McDermott DF, Kluger HM, Carvajal RD, Sharfman WH, Brahmer JR, Lawrence DP, Atkins MB, Powderly JD, Leming PD, Lipson EJ, Puzanov I, Smith DC, Taube JM, Wigginton JM, Kollia GD, Gupta A, Pardoll DM, Sosman JA, Hodi FS: Survival, durable tumor remission, and long-term safety in patients with advanced melanoma receiving nivolumab. J Clin Oncol 2014, 32:1020-1030.

115. Ansell SM, Hurvitz SA, Koenig PA, LaPlant BR, Kabat BF, Fernando D, Habermann TM, Inwards DJ, Verma M, Yamada R, Erlichman C, Lowy I, Timmerman JM: Phase I study of ipilimumab, an anti-CTLA-4 monoclonal antibody, in patients with relapsed and refractory B-cell non-Hodgkin lymphoma. Clin Cancer Res 2009, 15:6446-6453.

116. O'Sullivan Coyne G, Madan RA, Gulley JL: Nivolumab: promising survival signal coupled with limited toxicity raises expectations. J Clin Oncol 2014, 32:986-988.

117. Baeuerle PA, Reinhardt C: Bispecific T-cell engaging antibodies for cancer therapy. Cancer Res 2009, 69:4941-4944.

118. Topp MS, Zugmaier G, Goekbuget N, Kufer P, Goebeler M, Klinger M, Degenhard E, Baeuerle PA, Schmidt M, Nagorsen D, Neumann S, Horst HA, Raff T, Viardot A, Stelljes M, Schmid M, Ottmann OG, Burmeister T, Einsele H, Riethmueller G, Hoelzer D, Bargou RC: Report of a Phase II Trial of SingleAgent BiTE(R) Antibody Blinatumomab in Patients with Minimal Residual Disease (MRD) Positive B-Precursor Acute Lymphoblastic Leukemia (ALL). ASH Annu Meet Abstr 2009, 114:840.
119. Topp MS, Kufer P, Gökbuget N, Goebeler M, Klinger M, Neumann S, Horst H-A Raff T, Viardot A, Schmid M, Stelljes M, Schaich M, Degenhard E, Köhne-Volland R, Brüggemann M, Ottmann O, Pfeifer $H$, Burmeister T, Nagorsen D, Schmidt M, Lutterbuese R, Reinhardt C, Baeuerle PA, Kneba M, Einsele H, Riethmüller G, Hoelzer D, Zugmaier G, Bargou RC: Targeted Therapy With the T-Cell-Engaging Antibody Blinatumomab of Chemotherapy-Refractory Minimal Residual Disease in B-Lineage Acute Lymphoblastic Leukemia Patients Results in High Response Rate and Prolonged Leukemia-Free Survival. J Clin Oncol 2011, 29:2493-2498.

120. Goebeler M, Pfreundschuh M, Adrian N, Libicher M, Degenhard E, Stieglmaier J, Zhang A, Nagorsen D, Bargou RC: Open-Label Phase 2 Study Of The Bispecific T-Cell Engager (BiTE ${ }^{\top}$ ) Blinatumomab In Patients With Relapsed/Refractory Diffuse Large B-Cell Lymphoma. Blood 2013, 122:1811.

121. Bargou R, Leo E, Zugmaier G, Klinger M, Goebeler M, Knop S, Noppeney R, Viardot A, Hess G, Schuler M, Einsele H, Brandl C, Wolf A, Kirchinger P, Klappers P, Schmidt M, Riethmuller G, Reinhardt C, Baeuerle PA, Kufer P: Tumor regression in cancer patients by very low doses of a $T$ cell-engaging antibody. Science 2008, 321:974-977.

122. Viardot A, Goebeler M, Noppeney R, Krause SW, Kallert S, Ferstl B, Mackensen A, Rupertus K, Soekler M, Kanz L, Knop S, Topp MS, Scheele J, Nagorsen D, Zugmaier G, Degenhard E, Schmidt M, Kufer P, Libicher M, Einsele H, Bargou R: Blinatumomab Monotherapy Shows Efficacy in Patients with Relapsed Diffuse Large B Cell Lymphoma. ASH Annu Meet Abstr 2011, 118:1637.

123. Wolchok JD, Hoos A, O'Day S, Weber JS, Hamid O, Lebbé C, Maio M Binder M, Bohnsack O, Nichol G, Humphrey R, Hodi FS: Guidelines for the Evaluation of Immune Therapy Activity in Solid Tumors: Immune-Related Response Criteria. Clin Cancer Res 2009, 15:7412-7420.

124. Pardoll D: AACR Cancer Report 2013 - Special Feature on Immunotherapy. Clin Cancer Res 2013, 19(Supplement 1):S1-S88.

\section{doi:10.1186/s13045-014-0058-4}

Cite this article as: Suresh et al:: New antibody approaches to

lymphoma therapy. Journal of Hematology \& Oncology 2014 7:58.

\section{Submit your next manuscript to BioMed Central and take full advantage of:}

- Convenient online submission

- Thorough peer review

- No space constraints or color figure charges

- Immediate publication on acceptance

- Inclusion in PubMed, CAS, Scopus and Google Scholar

- Research which is freely available for redistribution 